\title{
Memory, Trauma and the Securitization of Migration in Contemporary Hungary
}

\author{
Maria João Militão Ferreira* \\ * Instituto Superior de Ciências Sociais e Políticas - Universidade de Lisboa, Portugal
}

\section{Resumo}

Este artigo discute as estratégias discursivas empregues pelo Primeiro-Ministro Húngaro Viktor Orbán e que materializam a securitização da migração através da invocação de elementos mnemónicos, designadamente, a memória e o trauma. As estratégias discursivas identificadas foram produzidas no contexto da crise europeia de refugiados. A literatura internacionalista tem debatido as práticas discursivas e não discursivas que resultam na securitização da migração. Todavia, a literatura não tem desenvolvido a articulação entre (in) segurança, migração, memória e trauma. O artigo baseia-se na Análise Crítica do Discurso e na geopolítica crítica para discutir como o discurso político pode enquadrar o fenómeno migratório partindo de uma perspetiva securitária e recorrendo a argumentos mnemónicos. Foram identificadas diversas categorias discursivas que correspondem à referida articulação. Argumenta-se que discutir a migração estabelecendo essa articulação permite a Orbán (re) construir a localização ontológica da Hungria deslocalizando-a para a Europa Central e de Leste e para a esfera russa de interesses.

Palavras-chave: discurso; Hungria; (in)segurança; memória; migração; trauma

\begin{abstract}
This article discusses discursive strategies employed by Hungary's Prime Minister Viktor Orbán that embody the securitization of migration through mnemonic elements, namely, memory and trauma. The discursive policies that have been identified were produced in the context of the European refugee crisis. Literature in International Relations has debated the discursive and non-discursive practices that result in the securitization of migration, yet there exist few studies that articulate the junctions of (in)security, migration, memory and trauma. This article draws from Critical Discourse Analysis and critical geopolitics to discuss how political discourse can frame migration from a security perspective through the use of mnemonic arguments. Textual categories corresponding to intersections of migration, (in) security, memory and trauma were identified. I argue that linking migration to these topics has allowed Orbán to (re)construct Hungarian ontological location, relocating the country in relation to Central and Eastern Europe and placing it within the arena of Russian influence. Keywords: discourse; Hungary; (in)security; memory; migration; trauma
\end{abstract}




\section{Introduction}

Europe is living one of the most turbulent periods of its history. After a financial turmoil, a refugee crisis arose that demonstrated the existence of fractures among the European Union (EU) member-states. Several European countries contested the europeanization of refugee policies, namely, the policy for the resettling of refugees among EU member-states (Orbán, 2016a).

The Prime Minister of Hungary, Viktor Orbán, is at the forefront of such contestation (Orbán, 2016a). This article intends to discuss Orbán’s approach to migration and asylum through his discursive practices, highlighting how those practices argue the question of migration and asylum through mnemonic elements. Thirty-eight speeches and interviews delivered by Viktor Orbán, between 2014 and 2017 were addressed and five discursive strategies were identified: (1) "clash of civilizations", purposive non-integration and dissimulated goals, (2) sovereignty, securitization and national identity protection, (3) migrants as biopolitical threats, (4) occupation memories and trauma and (5) (re)defining Hungary's ontological and geopolitical location. The five discursive strategies that were identified are interdependent since they all contribute to the construction of a cascade securitary argument against Islamic migration flows sustained by mnemonic elements (Orbán, 2016a).

The article is structured in several sections. The first part discusses the articulation between memory, trauma and the securitization of migration in Hungary, contextualizing such articulation through some insights regarding Hungarian historical developments. The paper is theoretically framed combining literature in the field of critical geopolitics, trauma and cultural memory studies as well as cultural geography. The second part discusses the use of Critical Discourse Analysis (CDA) as a fundamental methodology within critical geopolitics and also clarifies the methodological options of the article, specifically, concerning discourse selection. The following sections develop the discursive strategies employed by Viktor Orbán and mentioned above. Finally, the manuscript concludes by resuming its main findings, namely that discussing migration by establishing articulations among (in)security, memory and trauma allow Orbán to (re)construct Hungarian ontological location, dislocating it towards Central and Eastern Europe and to the Russian influence arena.

\section{Memory, Trauma, Migration and Hungarian Historical Geography}

The articulations between memory, trauma, (in)security and migration are deeply cultural since they deal with how societies interpret the time of their historical existence (Edkins, 2003, pp. 1-19). The association between historical memory and cultural memory is crucial since the latter endows resonance to concrete historical facts (Halbwachs, 1950, pp. 25-28; Hutchinson, 2010, p. 69). Trauma, frequently, emerges in political discourse as an insurance that the past can be (re)constructed as a reality (Kaplan, 2005, pp. 1-23). Therefore, memory and trauma influence public policies through the production of political subjectivity (Hutchinson, 2010, p. 69). The production of political subjectivity is very relevant since memory and trauma help to shape political identities, particularly, what Light (2010) and Young (1453) designate 
as "spaces of the nation". The articulation between trauma, memory and geopolitics transforms the concept of territory, stimulating the emergence of concepts like "Amerasian geography" (Kim, 2004, p. 109), "memory geopolitics" (Zhurzhenko, 2007, p. 1) or "geographies of memory" (Legg, 2007, pp. 456-466; Till \& Kuusisto-Arponen, 2015, p. 293).

The importance of discursive analysis to the discussion of mnemonic practices underpins the contributions of critical geopolitics for the field of memory studies (Ó Tuathail, 1999). This analytical approach of geopolitical thought considers that geopolitical discourses constitute theoretical conductors that allow deconstructing the meaning of territorial spaces (Kim, 2004; Ó Tuathail, 2005). Accordingly, just like "geographical spaces", trauma and memory might also be defined as "geographical sites" constituted by discursive regimes (Legg, 2007, pp. 456-466; Ó Tuathail, 2005). In this context, how mnemonic practices influence geopolitical representations assumes fundamental importance for critical geopolitics (Dittmer, 2010, p. 158). The concept of "memory geopolitics" highlights how mnemonic elements assume a component of robust articulation between the geographies of space and power (Zhurzhenko, 2007, p. 1).

The concept of "geographies of memory" reinforces the importance of cultural memory studies and cultural geography for the study of how migration can be framed through the articulation between trauma and memory (Till \& Kuusisto-Arponen, 2015, p. 293). In the words of Till and Kuusisto-Arponen (2015, p. 291), discussions on the significance of "place" emerge in contexts where "unsettled pasts resurface unexpectedly in ways that dislocate present day uses". The inflow of refugees can be understood in a context where the current use of the territory was "dislocated" which led to discursive regimes based on "unsettled pasts" (Till \& Kuusisto-Arponen, 2015, p. 291). If the past can have a condition of "unsettlement" (Till \& Kuusisto-Arponen, 2015, p. 291), trauma bears a condition of "mobility across spaces, places and times" (Coddington \& Micieli-Voutsinas, 2017, p. 1). Such mobility happens through processes of embodiment since trauma "travels in and through bodies" highlighting its emotional dimension (Coddington \& Micieli-Voutsinas, 2017, p. 1).

In the case of refugees' flows to Europe, Hungarian official narratives have established an association between the "significance of the past in the present" and the "spatial contexts of memory" (Till \& Kuusisto-Arponen, 2015, p.291). As can be seen through Orbán discourses, such an association explores what Till and Kuusisto-Arponen (2015, p. 291) designate as "emotional geographies". The concept of memory is highly contested (Erll, 2011). In fact, it was the return of nationalism that fostered the proliferation of memory studies (Olick, Vinitzky-Seroussy \& Levy, 2011, p. 3). However, the relationship between memory, trauma and governmental politics has always been difficult (Edkins, 2003). As Pierre Nora argues, through his concept of "lieux de mémoire", "sites of memory" emerge due to the non-existence of "real environments of memory" (Nora, 1989, p. 7). Such absence allows for the manipulation of mnemonic elements, particularly, in societies affected by historical discontinuities (Nora, 1987). Concerning Central and Eastern Europe, World War II and the subsequent Soviet rule have caused such historical discontinuities by "interrupting" histories of "ethnic diversity" (Piekut \& Valentine, 2017, p. 175). In this context, the 
recent question of refugees trying to reach European countries produced "xenophobic" reactions that should be understood as the outcome of specific "histories and geographies" (Valentine, Piekut, Winiarska, Harris \& Jackson, 2015, p. 568).

The discourses of some European leaders in the context of the refugee crisis has demonstrated the adoption of securitary and ecologic approaches to migration that stresses how migrants constitute a threat, not only to the security but mainly to the identity of host countries (Marcelino, Ferreira \& Mazzaglia, 2016). In Hungary, Prime Minister Viktor Orbán has entitled his perspectives on migration and asylum under the designation of "Kulturkampf", understood as a strategy to defend his Christian and nationalist perspectives (Mayer \& Prantner, 2015, p. 4). Viktor Orbán's “cultural struggle" consists of a wide project whose goal is to impose Orbán's "right-wing and xenophobic ideology on all walks of life" (Paterson, 2012, p. 8).

Literature has tried to understand the reasons that account for Central and Eastern European leaders' hard views on refugees (Mayer \& Prantner, 2015). Mayer and Prantner (2015, pp. 13-14) argue that Central and Eastern European leaders' perspectives may be explained through mnemonic arguments, namely these countries' historical experiences of occupation that have fostered nationalist feelings. Decades of resistance to Soviet rule and occupation have shaped the character of contemporary Central and Eastern leaders who, frequently, invoke Christian resistance to uphold their beliefs (Mayer \& Prantner, 2015, p. 20). In the words of Mayer and Prantner (2015, p. 20), Central and Eastern leaders do not only uphold "religion and freedom against communism but mainly the west against refugees". Drakulic $(2015$, p. 1) also claims that mnemonic factors, namely the trauma and the "suffering" experienced by Central and Eastern European societies during periods of totalitarian rule, constitute a possible explanation for their present responses to the refugee's drama, since a "competition for victimhood" can be perceived between Central and Eastern European societies, who still feel they are victims of communism. Traumatic experiences under communist rule were associated with equally traumatic experiences under "Turkish, that is, Muslim rule" (Drakulic, 2015, p. 5). Such association and the memory of fights against the Turks to protect Christianity empower contemporary anti refugees' discourses (Drakulic, 2015).Muslim and Soviet traumas conducted to the fostering of xenophobic feelings against foreigners, particularly, those coming from specific geographies and to the need to ensure sovereign, independent and ethnically homogeneous national states (Drakulic, 2015; Mayer \& Prantner, 2015).

However, it is in Hungary that a campaign to securitize migration flows has had an increasing impact (Szalay \& Göbl, 2015, p. 2). As Szalay, and Göbl (2015, p. 2) argue, the upsurge in antagonism concerning refugees entering into Hungarian territory is directly related to governmental securitization operations. In Hungary, the prejudice against migrants has been fuelled by national authorities, allowing for the conclusion that, in this country, nationalism may be a very suitable "lens through which to understand prejudice" (Valentine et al., 2015, p. 568).

In fact, Hungary has suffered from diverse experiences of occupation, loss of sovereignty and territorial turmoil, which may be interpreted as constituting an explanation for governmental representations of migrants and refugees as threats to 
national attempts to (re)construct the nation, to decide who "belongs" to the community (Valentine et al., 2015, p. 568) and, above all, to autonomously proclaim a communitarian right to "prioritize" the control of national territory (Darling, 2010, p. 134). Viktor Orbán discursively "frames" the question of Muslim migration in Europe through what Tharoor $(2015$, p. 6) designates as "grand historic terms", fundamentally based on mnemonic elements, namely the invocation of "Hungary's history of conquest under the Ottoman Empire" (Tharoor, 2015, p. 10).

In Hungary, the percentage of migrants (4.56\%) is relatively low (Kirk, 2016). The Muslim minority represents fewer than $1 \%$ of the Hungarian population (Tharoor, 2015, p. 6). The European refugee resettlement scheme, decided by the EU, would represent, in the Hungarian case, about 307 refugees for a "total allocation based on 20.000 persons" (European Comission [EC], 2015, p. 36). In a referendum promoted by Viktor Orbán, held in 2016, concerning Hungarian refugee policy, the turnout was below 50\%, turning the referendum invalid (Barata, 2016, p. 1). However, amongst those who voted, more than $98 \%$ were against the EU refugee policies, namely the imposition upon Hungary of allocation quotas (Barata, 2016, p. 3). Referendum results can be interpreted as an embarrassment for Orbán and his plans for unleashing a cultural "counter-revolution" in Europe that would overthrow liberal ideas, namely refugee assistance, and establish traditional values like "identity-based notions of family, community and Christianity" (The Economist, 2016, p. 3). What, therefore, needs to be discussed is how Hungary's historical path helps to explain Orbán's discourses against migrants and refugees?

Ethnic diversity was a reality for the most of Hungary's history (Molnár, 2001). Between the eighteenth century and the twentieth century, the Hungarian territory was constituted by a slight majority of non-Magyar inhabitants who were never assimilated by the Magyar population (Molnár, 2001). The outcome of the Second World War led to the "brutal" eviction of Germans residing for centuries in Hungary (Keegan, 2005, p. 496). As Kegan (2005, p. 593) argues, the resettlement policies developed after the Second World War,

returned ethnic frontiers in Europe largely to those that had prevailed at the creation of Charlemagne's empire at the beginning of the ninth century, solved at a stroke the largest of 'minority problems', and ensured Soviet domination of central and eastern Europe for two generations to come.

Ethnic heterogeneity was replaced by ethnic homogeneity (Keegan, 2005). After the end of Soviet rule, Hungary went through a difficult transition to democracy, particularly in the mid-1990s, when nationalism and anti-Semitism became a part of the Hungarian political discourse (Molnár, 2001, p. 262). In Molnár's (2001, pp. 343-344) words:

[a]t the heart of the debate was a spurious problem: that of 'Magyarity': since society was broadly homogeneous and its relations with small minorities, with the exception of the Gypsies, fairly unproblematic, questions about 'Magyaryty' clearly related to one group (the Jews), one ideology (the alleged cosmopolitanism of those who were not Magyar enough) and one policy (economic liberalism). 
It should be noted that Hungary has a considerable number of ethnic Hungarians spread among neighboring countries (Marshall, 2017, p. 13). Also, political developments throughout the 1990s allowed the conclusion that the Hungarian population "largely refused market liberalism" which may explain the rise to power of FIDESZ (Saxonberg, 2001, p. 393). The stage was set for the arrival of Viktor Orbán to Hungarian politics.

\section{Critical Discourse Analysis: the Methodological Framework}

One of the main methodological instruments in the field of critical geopolitics is CDA (Müller, 2011). Discourse is considered one of the most important concepts for the study of geopolitical practices (Müller, 2011). Discourse allows the construction of "geographical understandings" (Ó Tuathail \& Agnew, 1992, p. 191). Policy issues, like migration, are "rendered meaningful through already existent "geographically-infused reasoning" (Ó Tuathail \& Agnew, 1992, p. 191). In the words of Ó Tuathail and Agnew (1992, p. 192), "geography as a discourse is a form of power/knowledge itself. Ó Tuathail and Agnew (1992, p. 192), therefore, propose a new definition of geopolitics as a practice materialized through discourse that allows decision-makers to give spatial meaning to the world, enhancing its specific geographies, humanities and dramas.

The theoretical roots of CDA are fundamentally articulated with a critical perspective concerning the performative role of social sciences (Fairclough \& Fairclough, 2012, pp. 78-81) since CDA can help to question how political discourses may "(re)produce social domination" (Van Dijk, 2009, p. 639). Literature employing CDA regards language as a "social practice" (Fairclough \& Wodak, 1997, p. 258) and focuses on how language, ideology and power are intertwined so to empower, reify or contest "structural relations" of "dominance" (Wodak, 2001, p. 2). The option to employ CDA as an epistemological and methodological tool compels authors to contemplate the historical contexts that frame social structures and discursive practices, specifically, regarding the discursive representation of public policies (Reisigl \& Wodak, 2001, p.41).

CDA has been employed to deconstruct the "speech acts" of political leaders, namely, concerning discursive legitimation strategies (Fairclough, 2003; Fonseca \& Ferreira, 2015; Van Dijk, 1998). It has also been applied in studies within the field of political science that address issues whose discursive dimension call for such kind of methodology (Van Dijk, 1997, p. 12). Migration as a social and public policy question is one of those issues (Charteris-Black, 2006). In the field of International Relations, CDA has also been employed as a methodology, namely, in studies that address the articulation between identity, discourse and political action (Casula \& Perovic, 2009) or in research in the arena of European foreign policy (Aidin-Düzgit, 2013).

Memory and trauma are recurrent themes in migration studies (Goldman, 2011). However, the focus is frequently located on migration flows and their traumatic experiences (Goldman, 2011) and not so much on host societies' mnemonic perspectives and discourses on migration questions. Those discourses are increasingly framed 
by the articulation between migration, (in)security, memory and trauma (Innes \& Steele, 2014).

Such articulation needs to be empirically documented through discourse analysis. The selection of discourse analysis as an epistemological tool allows for the establishment of a bridge with critical geopolitics (Müller, 2011). The goal is to argue that, in the particular case of Viktor Orbán, discussing migration by establishing articulations among (in)security, memory and trauma allows him to (re)construct Hungary's ontological and geopolitical location.

To discuss how Viktor Orbán has been establishing such an articulation, thirty-eight speeches and interviews, delivered by Orbán between 2014 and 2017, were selected. The selection of official speeches was made isolating the discourses where the question of migration and asylum were discussed by Orbán. The majority of those statements was retrieved from the Hungarian government official homepage. Speech selection was complemented with interviews made to the Hungarian Prime Minister. With the goal of ensuring the representativeness of the sample of discourses, a four-year temporal period was selected and the speeches chosen were made in distinct events of Hungarian political life. Since Orbán debates the question of migration and asylum very often, it was possible to identify five discursive categories that will be discussed in the following sections. Those categories are: (1) "clash of civilizations", purposive non-integration and dissimulated goals, (2) sovereignty, securitization and national identity protection, (3) migrants as biopolitical threats, (4) occupation memories and trauma and (5) (re)defining Hungary's ontological and geopolitical location. Representative excerpts of Orbán's speeches were organized into tables located at the end of each discursive category.

\section{1 "Clash of civilizations", Purposive Non-Integration and Dissimulated Goals}

As an argument, Bernard Lewis' (1990) "clash of civilizations" has a profound geopolitical nature, since it was devised to perpetuate conflict and cultural prejudice in international relations (Huntington, 2011; Saïd, 1996). The "clash of civilizations" stands out as one of the main discursive strategies of the Hungarian Prime Minister, since he recurrently accentuates the dangers arising from what he represents as the interaction between non-compatible civilizations (Orbán, 2016j). Orbán is explicit concerning the incompatibilities between Western and Muslim civilizations (excerpt 1), as well as regarding the main differences between "Europe" and the "Muslim world" (excerpt 2).

According to the argument concerning the "clash of civilizations", which is a key securitary explanation for understanding international events (Saïd, 1996), Orbán employs a language that inflates the dangers coming from refugee flows (Orbán, 2016a). In the case of excerpt 2, the argument concerning the differences between the two "civilizations" is associated with a biopolitical rationale that accentuates "an aging Europe and a young Muslim world". Also, multiculturalism is represented as a possible source of conflicts, since Orbán equates migration and refugee flow with territorial occupation (Orbán, 2016c). 
Associated with the use of a discourse underpinning the notions of territorial occupation, of the ethnic "restructuring" of the Hungarian population, of the "replacement of civilizations" and of the constitution of "parallel societies", all arguments very prone to the invocation of mnemonic feelings, it can also be observed the use of metaphors related to natural catastrophes, like "floods" and "storms" (excerpt 3 / excerpt 42). This kind of metaphors is recurrent in migration discourses (Charteris-Black, 2006).

Excerpts 3, 4 and 5 illustrate very well what literature within CDA, and predominantly, literature discussing "discriminatory discursive strategies" designates as "negative other presentation", meaning representing a group, through stigmatization and stereotyping, as having negative cultural characteristics, and as being a source of threat and deviant behaviour (Flowerdew, C. S. Li \& Tran,2002, p. 11).

Building fences are, in this context, a way for Orbán to ensure what Darling (2010, p. 134) designates as an autonomous communitarian power to "prioritize" the control of national territory. Such right is argued as endangered by the europeanization of migration policies and by what Orbán considers to be the real risk of the disappearance of European culture (Orbán, 2017i).

In association with the argument concerning the "clash of civilizations", another idea frequently employed by Orbán concerns purposive non-integration, meaning the evidence that migrants and asylum-seekers do not wish to integrate into host countries, but have malicious intentions, namely the occupation of Europe (excerpt 6).

Orbán puts himself in a counter-culture position, claiming that his arguments defy European political correctness and expose not random but previously organized motives of refugee flows (the "masses") coming to Europe (Orbán, 2016c). Excerpts 6 and 7 constitute paradigmatic examples of a particular "discriminatory discursive strategy": "delegitimation" (Flowerdew et al., 2002, p. 12). This discriminatory strategy" tries to "discredit" and "disempower" specific "minority groups" by characterizing them as "violators of pivotal social norms" (Flowerdew et al., 2002, p. 12).

The previously organized motives of refugee flows assume a securitary and an economic nature (excerpt 5). Following Orbán, refugee flows have the unlawful intent of keeping their traditions, while taking advantage of the "European standards of living" (excerpt 6). The argument on purposive non-integration is articulated with the reification of the belief that refugees have dissimulated goals and that their qualification as asylum seekers is not credible since their intentions are mainly economic (excerpt 7). Following Orbán, however, it is impossible to distinguish between genuine refugees and false asylum-seekers (excerpt 8). Orbán proposes to establish a screening process for refugees outside EU borders (excerpt 9). However, he also claims that only Europeans fleeing their homes due to refugee flows can qualify as real refugees (excerpt 12).

However, two more ideas are reified by Orbán concerning the dissimulated goals of migrants. Firstly, the idea that refugee's distribution through quotas is "inhumane" because the goal of refugees is to go to Germany (excerpt 10). Finally, Orbán explicitly argues that refugees are potential left-wing supporters, which means that refugee flows are a way to "import left-wing voters to Europe" (excerpt 11). 
Table 1. "Clash of civilizations", purposive non-integration and dissimulated goals

\begin{tabular}{|c|c|}
\hline Excerpt 1 & $\begin{array}{l}\text { "The civilization that stems from Christianity and the civilization that stems from Islam are } \\
\text { not compatible" (Orbán, 2016j). }\end{array}$ \\
\hline Excerpt 2 & $\begin{array}{l}\text { "The reality is that unless we put our foot down very soon, we will see an unmanageable level } \\
\text { of tension between an aging Europe and a young Muslim world, between a secular and faith- } \\
\text { less Europe and an increasingly fervent Islamic world" (Orbán, 2016b). }\end{array}$ \\
\hline Excerpt 3 & $\begin{array}{l}\text { "We do not want parallel societies, we do not want the restructuring of our population, and we } \\
\text { do not want to replace Christian civilization with a different form. [t]herefore, (..) we are not } \\
\text { allowing migrants to flood us" (Orbán, 2017i). }\end{array}$ \\
\hline Excerpt 4 & $\begin{array}{l}\text { "The reality is that those coming here have no intention whatsoever of adopting our way of } \\
\text { life because they see their own as more valuable, stronger and more viable than ours" (Orbán, } \\
\text { 2016b). }\end{array}$ \\
\hline Excerpt 5 & $\begin{array}{l}\text { Migration turned out to be the Trojan horse of terrorism. [m]igration turned out to be a false } \\
\text { solution to labor shortages (Orbán, 2017k). }\end{array}$ \\
\hline Excerpt 6 & $\begin{array}{l}\text { "The people who seek to come here do not want to live according to our culture and customs, } \\
\text { but according to their own - with European standards of living" (Orbán, 2017n). }\end{array}$ \\
\hline Excerpt 7 & $\begin{array}{l}\text { "These people are not coming to Europe because they seek safety, but because they want a } \\
\text { better life than that in the refugee camps" (Orbán, 2015f). }\end{array}$ \\
\hline Excerpt 8 & "There was no chance of us screening out those who posed a danger to us" (Orbán, 2016b). \\
\hline Excerpt 9 & $\begin{array}{l}\text { "The goal is not to manage migration well, but to stop their entry: to stop them outside our } \\
\text { borders, and there, separate genuine refugees from other migrants" (Orbán, 2017l). }\end{array}$ \\
\hline Excerpt 10 & $\begin{array}{l}\text { "The first is that it is an inhumane proposal (migrant's quotas distribution) because if someone } \\
\text { is transported to some other place, they will have to be tied to a tree there, as otherwise, they } \\
\text { will simply go back to Germany" (Orbán, 20161). }\end{array}$ \\
\hline Excerpt 11 & $\begin{array}{l}\text { "All indirect evidence and experience point to the vast majority of these migrants later becom- } \\
\text { ing left-wing voters, once they have settled down. Consequently, future left-wing voters are } \\
\text { being imported into Europe. [f]rom a legal point of view, however, the situation is clear: there } \\
\text { are no grounds for asylum" (Orbán, 2015d). }\end{array}$ \\
\hline Excerpt 12 & $\begin{array}{l}\text { "We will, of course, be letting in genuine refugees: Germans, Dutch, French and Italians, terri- } \\
\text { fied politicians and journalists, Christians who have been forced to leave their homes and who } \\
\text { here in Hungary want to find the Europe they have lost in their homelands" (Orbán, 2017k). }\end{array}$ \\
\hline
\end{tabular}

\subsection{Sovereignty, Securitization, and National Identity Protection}

Viktor Orbán's arguments against refugee flows depart from what he interprets as the Hungarian need to maintain its cultural and civilizational integrity (excerpt 13). Arguing migration and refugee flows as questions of "existential significance" (excerpt 14) conducts to the usage of a securitary language that overestimates the existential, security and cultural threats represented by migration flow to contemporary societies (Orbán, 2015a). Therefore, a language of survival is frequently employed (excerpt 15).

Excerpts 15 and 18 constitute examples of another "discriminatory discursive strategy", specifically, "scare tactics", through which the migrants are represented as 
an "alleged threat to the interests and privileges of the dominant group" (Flowerdew et al., 2002, p. 11). Discourses using this "discriminatory strategy" employ exaggerated figures in order to cause panic: "extinction", "survival", "dramatic increases in crime", "assault", "horrors" or "wave of fundamentalists" (Flowerdew et al., 2002, p. 11; Orbán, 2015a, 2017j).

A securitary language and a rhetoric of survival is associated, in Orbáns' discursive economy, to the legitimation of border patrolling policies, including the construction of the fence to halt refugee flows, to the highlighting of defense policies, characterized as a "fundamental instinct", and to the normalization of the idea that migrants constitute natural sources of aggression (excerpts 16 and 17). Border patrolling policies assume two meanings in Orbán discourse: the Hungarian and Europeans borders are physical, but the borders also have a moral dimension (Smith, 2010). Such moral dimension leads Orbán to accentuate how refugee flows endanger the Christian European heritage, which Orbán represents as potentially feebler compared to other cultures (excerpt 18), as well as threaten the Hungarian political system (excerpt 21). The alleged defense of the European moral heritage conducts Orbán to discursively construct an antagonism between national states and the European Union, accused by Orbán of not respecting the ideal of national sovereignty, of wanting to impose a "United States of Europe", of europeanizing migration policies - namely through refugee policies - and of reifying liberal ideas, explicitly, that refugees do not constitute a threat and that multiculturalism is a good policy (excerpts 19 and 20).

The denial to accept multiculturalism drove Orbán to refuse the European refugee allocation system, to call for a referendum on such matter, to represent multiculturalism as a "problem", and, finally, to uphold that refugees should not have basic political rights, not even the right to a "better life" (excerpts 22 and 23).

Table 2. Sovereignty, securitization, and national identity protection

\begin{tabular}{ll}
\hline Excerpt 13 & "We want to preserve Hungary as a Hungarian country" (Orbán, 2015a). \\
\hline Excerpt 14 & "The migration flow is a historic challenge of existential significance" (Orbán, 2016d). \\
\hline Excerpt 15 & $\begin{array}{l}\text { "What is at stake today is Europe and the European way of life, the survival or extinction } \\
\text { of European values and nations - or, to be more precise, their transformation beyond all } \\
\text { recognition" (Orbán, 2015a). }\end{array}$ \\
\hline Excerpt 16 & $\begin{array}{l}\text { "It is difficult to understand the weakening of our civilization's natural and fundamental } \\
\text { instinct for the defense of ourselves, our families, our homes and our land" (Orbán, 2016b). }\end{array}$ \\
\hline Excerpt 17 & $\begin{array}{l}\text { "There are always countries which want to preserve their Christian cultural identity, while } \\
\text { others want to disregard this, a decisive battle is about to develop here" (Orbán, 2017g). }\end{array}$ \\
\hline Excerpt 18 & $\begin{array}{l}\text { "If Europe allows cultures to compete, then the Christians will find themselves on the losing } \\
\text { side" (Orbán, 2015f). }\end{array}$ \\
\hline "Similarly, a fair number of centers of financial and political power in Brussels also have a \\
$\begin{array}{l}\text { vested interest in erasing national structures, and eliminating national identities" (Orbán, } \\
\text { 2015a). }\end{array}$
\end{tabular}




\begin{tabular}{ll}
\hline Excerpt 20 & $\begin{array}{l}\text { "Instead, they (EU leaders) say, people (migrants) can freely go to wherever such a life is } \\
\text { available. [i]f we allow space for this belief it will destroy Europe, its culture and its eco- } \\
\text { nomic system" (Orbán, 2016k). }\end{array}$ \\
\hline Excerpt 21 & $\begin{array}{l}\text { "Muslims will establish their own parties as soon as their populations are high enough" } \\
\text { (Orbán, 2016k). }\end{array}$ \\
\hline Excerpt 22 & "A better life cannot be seen as a fundamental right" (Orbán, 20160). \\
\hline Excerpt 23 & $\begin{array}{l}\text { "Today, however, increasing numbers of people see multiculturalism not as a solution to } \\
\text { problems, but as the cause of them" (Orbán, 2015a). }\end{array}$ \\
\hline
\end{tabular}

\subsection{Migrants as Biopolitical Threats}

The argument that migrants constitute biopolitical threats is developed through demographic allegations, namely, that migrants have higher fertility rates than the populations of their host countries (excerpt 24). Orbán claims that refugee flows will cause demographic and ethnic imbalances, which will assume "existential" dimensions in regarding endangering the survival of "indigenous" populations (excerpts 24, 25). Demographical imbalances are heightened, so Orbán claims, by the fact that there is an intention of purposive non-integration between Muslim and Christian communities, materialized in the impossibility of inter-ethnic marriages and by the reality of parallel societies (excerpt 26 and 27). There is also the discursive suggestion that the majority of refugee flows are young men at the peak of their reproductive lives (excerpt 26).

It has to be taken into consideration that Hungary is an ethnically homogeneous country only since the end of World War II (Kegan, 1997, p. 496). This fact gives emotional resonance to Orbán's claims that Hungarians are threatened by refugee flows and that the European system for refugee allocation may reverse the ethnic composition of the country (excerpt 28).

Excerpts 25, 27, 28, 31 and 32 are examples of a fourth "discriminatory discursive strategy" designated as "blaming the victim", through which there is an attempt to "justify" discriminatory attitudes concerning certain minority groups, who are transformed into "scapegoats", thus reinforcing their alleged "guilt" concerning the "course of events", as well as strengthening the opposition between "we" (the majority) and "them" (the minority) (Flowerdew et al., 2002, p. 11).

One of the solutions for the demographic and biopolitical problem identified as a threat by Orbán is, in his perspective, to adopt public policies centered on the family and spiritual renewal (excerpt 29). Viktor Orban's rhetoric is focused on arguing that refugees and migrants, namely young male refugees, are a threat not only to future generations but also to women. That explains why he refers to the trauma of the alleged 2015/2016 sexual assaults in Cologne (excerpt 30).

Finally, to endow his discursive utterances with credibility, and since some of his claims constitute clear fallacies, Orbán inflates his allegations by using emotional language, metaphors and hyperboles (excerpt 31 to excerpt 33). 
Table 3. Migrants as biopolitical threats

\begin{tabular}{|c|c|}
\hline Excerpt 24 & $\begin{array}{l}\text { "The Muslims undertake to have many children, more than we, Europeans do. [w]e, Euro- } \\
\text { peans place ourselves before everything, including children sometimes. If we take in Mus- } \\
\text { lims in large numbers, it is a simple mathematical question to estimate what the country } \\
\text { will look like in } 20 \text { years' time" (Orbán, 2016j). }\end{array}$ \\
\hline Excerpt 25 & $\begin{array}{l}\text { "This is a matter of life and death: we are talking about fundamental issues related to our } \\
\text { very existence. [i]f we look at the shifting ethnic balances and the difference in fertility rates } \\
\text { between the indigenous population and those who have newly arrived, simple mathematics } \\
\text { tell us how many years it will take before there are as many of them as of us, and when they } \\
\text { will be the majority" (Orbán, 2016k). }\end{array}$ \\
\hline Excerpt 26 & $\begin{array}{l}\text { "It takes a vivid imagination to believe that young Afghan men will marry into traditional } \\
\text { German Christian families or Christians into Muslim families en masse" (Orbán, 2016k). }\end{array}$ \\
\hline Excerpt 27 & $\begin{array}{l}\text { "In states with traditional Christian-based legal systems, there are Arab families who may } \\
\text { comply with the law on the surface, but who in reality live their private lives according to } \\
\text { the culture and legal system of their country of origin" (Orbán, 2016k). }\end{array}$ \\
\hline Excerpt 28 & $\begin{array}{l}\text { "And one morning we could wake up and realize that we are the minority on our own con- } \\
\text { tinent" (Orbán, 2015c). }\end{array}$ \\
\hline Excerpt 29 & $\begin{array}{l}\text { "And there is another view, held by Central Europe - and, within it, Hungary. [o]ur view is } \\
\text { that we must solve our demographic problems by relying on our own resources and mobi- } \\
\text { lizing our own reserves... by renewing ourselves spiritually" (Orbán, 2017c). }\end{array}$ \\
\hline Excerpt 30 & $\begin{array}{l}\text { "I do not want my children to grow up in a world where something like Cologne can hap- } \\
\text { pen" (Orbán, 2016a). }\end{array}$ \\
\hline Excerpt 31 & $\begin{array}{l}\text { "If somebody takes masses of non-registered immigrants from the Middle East into a coun- } \\
\text { try, this also means importing terrorism, criminalism, anti-Semitism and homophobia" } \\
\text { (Orbán, 2016a). }\end{array}$ \\
\hline Excerpt 32 & $\begin{array}{l}\text { "Mass migration is a low stream of water persistently eroding the shores. [i]t is masquer- } \\
\text { ading as a humanitarian cause, but its true nature is the occupation of territory" (Orbán, } \\
2016 c \text { ). }\end{array}$ \\
\hline Excerpt 33 & $\begin{array}{l}\text { "We cannot fail to mention that we are all - both you and we - in the midst of a major Eu- } \\
\text { ropean debate. To simplify the essence of this debate, the question here is this: migrants or } \\
\text { our own families" (Orbán, 2017d). }\end{array}$ \\
\hline
\end{tabular}

\subsection{Occupation Memories and Trauma}

The use of textual references to mnemonic elements in Viktor Orbán's discursive regime is a pillar of his communication strategy. It involves, above all, references to historical events and personalities, in an almost messianic attempt to intertwine the present with the past, linking those events, specifically traumatic events, with present Hungarian public policies in the migration and asylum arenas (excerpts 34 and 35). Also, the Hungarian Prime Minister frequently establishes a historical comparison among refugee flows, represented as "enemies of freedom" and traumatic occupation episodes in Hungarian history (excerpt 36, 37 and 38).

Another discursive instrument that is based on the invocation of mnemonic elements is Orbán's recurrent use of securitary language to appeal to Hungarians' 
historical instinct of resistance towards refugee flows, represented as the source of "civilizational shocks", as well the mnemonic allegation that history is continuously challenging the Hungarian people (excerpts 39, 40, 41 and 42).

Finally, besides representing refugees as a new form of occupying forces, Viktor Orbán also establishes an articulation between Muslim refugees and the European leftist movements, both argued as internationalist ideologies and phenomena, which is a way for Orbán to claim that migration flows are incompatible with the preservation of autonomous nation-states, something that, in his perspective, is the "long term-goal" of leftist movements (excerpt 43). The reference to the reintroduction of communism (excerpt 43) is meant to highlight the last occupation moment experienced by Hungarians and that is still very intense in their memories.

Table 4. Occupation memories and trauma
Excerpt 34 "We are giving personnel, border guards, technical hardware and equipment to the Balkan countries because it is they who are in reality defending Europe's borders. [a]nd while they are resisting, we will also be able to defend our own borders more easily. [w] have known this since the time of Hunyadi" (Orbán, 2016b). Excerpt 35v “Today, 168 years after the great Wars of Independence of the European peoples, Europe, our
common home is not free!” (Orbán, 2016c).

Excerpt 36 "Whenever Hungary was invaded - whether from the West or the East - what followed was suffering on an unimaginable scale. [t] he story of the suffering of the ethnic Germans in Hungary should remind us that it is one's inalienable right to live where one was born: to live in the culture, the country and the settlement which one considers to be one's home" (Orbán, 2016t).

Excerpt 37 "History has kicked down the door on us: it has laid siege to the borders of Europe and the security of European cultures and European citizens" (Orbán, 2016b).

Excerpt 38 “Today's enemies of freedom are cut from a different cloth than the royal and imperial rulers of old or those who ran the Soviet system; they use a different set of tools to force us into submission" (Orbán, 2016c).

Excerpt 39 "When we celebrate, we do not forget that all our freedom fights - one by one - ended in occupation” (Orbán, 2017m).

Excerpt 40 "The European continent has received few civilizational shocks and threats which did not, one way or another, pass through us - or, rather, trample on us. [t] herefore, the gut instinct which always leads us to first think about what kind of danger we are facing is in no way exaggerated" (Orbán, 2016f).

Excerpt 41 "Our hearts have been welded together by the battle in which we beat back the mass population movement which is besieging Europe” (Orbán, 2017m).

Excerpt 42 "Today, once again, we must protect the southern borders of Europe. [th]is task falls on those who not only have long histories but also have long memories. [f]or more than a thousand years we Hungarians ... have withstood the storms of history” (Orbán, 2016g).

Excerpt 43 "The European left... do not see immigration as a source of danger but as an opportunity. [t] he left has always looked upon nations and national identity with suspicion. [ $\mathrm{t}$ ]hey believe (and take note of their choice of words) that the escalation of immigration may fatally weaken - indeed eliminate - national borders, and in historical terms, this would also constitute the attainment of the left's as yet unimaginable long-term goal" (Orbán, 2015a). 


\section{5 (Re)defining Hungary's Ontological and Territorial Space}

As already stated, the argument developed in this paper is that discussing migration through the establishment of articulations among (in)security, memory and trauma allows Viktor Orbán to (re)construct Hungarian ontological and geopolitical location, dislocating it from Western Europe towards Central and Eastern Europe as well as to the Russian area of influence. Such (re)construction is explicit in his discursive practices. Orbán argues that, within international politics, the geographical "location" of a country is not equal to its ontological and geopolitical "location", and that the latter may change either by force or by free will (excerpt 44 ).

Faced with what Orbán regards as the contingency of geopolitical locations and belongings, he argues that Hungary should once more shift its geopolitical and ontological "location" back to Central and Eastern Europe and closer to Russia, and away from the European Union that Orbán represents as promoting an attitude of "Willkommenskultur" concerning migrants and refugees (excerpt 47). The causes for such shift are also represented as being economic since Orbán believes that the key to the recovery of the European economy is in Central and Eastern Europe, as well as in Asia, namely in China (excerpts 45 and 46). However, it is evident that Orbán desires to demonstrate his rejection regarding the path followed, from 2015 onwards, by the European Union, in what concerns migration and asylum policies (excerpt 48 and 49).

In his discursive regime, Viktor Orbán establishes a parallel among, on the one hand, the European Union as an international organization that is gradually transferring sovereignty from the states towards Brussels and, on the other hand, "countless", criminal and violent refugees who, following Orbán's perspective, come with the purpose of occupying Hungarian territory and of reversing the ethnic composition of national states (excerpt 48). Such a parallel emerges from an ideological antagonism, argued by Orbán, and that constitutes one of the foundations of his discursive framework: the antagonism between national states and what Orbán designates as "internationalism" embodied in the European Union and on migration flows (excerpt 50). Such ideological antagonism becomes more explicit when Orbán compares the European Union to an "empire" (Orbán, 2016h). The opposition between national-states and empires has been a constant of European politics since, at least, the XVII century (Smith, 2010), which means that Orbán's discursive reference is loaded with mnemonic elements.

Following Orbán, it is the ideology of "internationalism" (Orbán, 2016c) that leads the European Union to adopt a liberal and human's rights approach towards refugees (excerpt 49). Recurring to mnemonic invocations, Orbán explicitly declares his nationalism, as well as the idea that Hungary is opposed to internationalist forces and will follow a national "path" (excerpt 50). Also, Orbán proclaimed that the "era of multilateralism is at an end and that the era of bilateral relations is upon us", which he considers being a good thing for Hungary since, in his words, "it is an unnatural state of affairs when influenced by external pressure, one dare not state that one's own country comes first when governing" (Orbán, 2017o). 
As I have already mentioned, Orbán proposes a shift in Hungarian geopolitical and ontological "location" away from Western Europe and back to Central and Eastern Europe and, particularly, to the Russian sphere of influence, strengthening relations with the leading countries in the area. What is interesting to observe is that this proposal to shift the geopolitical and ontological location of Hungary is argued through mnemonic references, namely traumatic mnemonic references (excerpt 51). Another way for Orbán to justify the ontological and geopolitical Hungarian shift towards Central and Eastern Europe is stressing the dependency of the Hungarian economy concerning eastern economy, namely Russian economy, regarding whom Hungary maintains a gas dependency of 60\% (Marshall, 2017, p. 37) (excerpts 52 and 53). Finally, Orbán's discursive practices underpin the commonality of Russian and Hungarian political and strategic cultures (excerpt 54).

Table 5. (Re)defining Hungary's ontological and territorial space

Excerpt 44 "In world politics, an entire country may also change its location without its borders mov-
ing an inch. [w]e, for instance, were occupied by the Soviet Army, and from one minute
to the next we were shifted from the West to the East. [1] ater they withdrew, and we found
ourselves back in the West again" (Orbán, 2016b).

Excerpt 45 "The engine room of the global economy is no longer in the West, but in the East - or, rather, the East has caught up with the West. [t]he Chinese are the strongest - so they've launched another direction of movement, which is called 'One Belt, One Road'. [t] his is specifically built on mutual acceptance: there is no teacher and no student. [ $\mathrm{t}$ ]he President of China has said that everyone has the right to their own social structure, culture, approach and values" (Orbán, 2017e).
Excerpt 46 "Economic growth will be generated in Central Europe, and if it were not for us, if we were not successful, then there would be no economic growth in Europe” (Orbán, 2016s).
Excerpt 47 "In 2015 everything changed. [o]ne morning, out of the blue, we woke up to the sound of 'Willkommenskultur”' (Orbán, 2016b).

Excerpt 48 "It is forbidden to say that in Brussels they are concocting schemes to transport foreigners
here as quickly as possible and to settle them here among us. [i]t is forbidden to point out
that the purpose of settling people here is to reshape the religious and cultural landscape
of Europe, and to reengineer its ethnic foundations - thereby eliminating the last barrier
to internationalism: the nation-states. [i]t is forbidden to say that Brussels is now stealthily
devouring more and more slices of our national sovereignty and that in Brussels many are
now making a plan for a United States of Europe - for which no one has ever given author-
ization" (Orbán, 2016c).

Excerpt 49 "In Brussels, discourse about migration is still a prisoner of political correctness. [t]hey still regard only those who speak in the voice of human rights activists and the European liberal elite as being acceptable” (Orbán, 2017c).

Excerpt 50 "After its leaves and branches (of internationalism) have withered, its roots will also dry up in the Hungarian motherland's soil, which is hostile to internationalism. [1] et us give thanks that this may be so, let us give thanks that finally, the Lord of History has led us onto this path. Soli Deo Gloria!" (Orbán, 2016c).

Excerpt 51 "We Central Europeans know from historical experience that sooner or later we will lose our freedom if we do not represent the interests of our citizens" (Orbán, 2016a). 


\begin{tabular}{ll}
\hline Excerpt 52 & $\begin{array}{l}\text { "Without good economic relations between Russia and Hungary, the Hungarian economy } \\
\text { and Hungarian industry will simply be unable to function" (Orbán, 2016r). }\end{array}$ \\
\hline Excerpt 53 & $\begin{array}{l}\text { "Without the Russians, it's impossible to manage rightly the future of the Hungarians" (Or- } \\
\text { bán, 2015i). }\end{array}$ \\
\hline Excerpt 54 & $\begin{array}{l}\text { "The only way if you would like to have a good [relationship] with the Russians is power } \\
\text { policy based on reality. [i]f you would like to have a relationship with the Russians based } \\
\text { on principles it will never work... [s]o put aside principles, ideologies and look at the inter- } \\
\text { est, and find the common-sense realpolitik agreements. [t]hat's the Hungarian approach" } \\
\text { (Orbán, 2015i). }\end{array}$
\end{tabular}

\section{Conclusion}

This paper has argued that discussing migration and asylum by establishing articulations among (in)security, memory and trauma allows the Prime Minister of Hungary, Viktor Orbán, to (re)construct Hungarian ontological location, dislocating it geopolitically from Western Europe towards Central and Eastern Europe as well as towards Russia's geopolitical sphere of influence. Orbán claims that the geographical "location" of a country is not equal to its ontological and geopolitical "location" and that the latter may change either by force or by free will (Orbán, 2016b).

Methodologically, the paper departed from Critical Discourse Analysis. The analysis of thirty-eight speeches and interviews, delivered by Orbán between 2014 and 2017 allowed for the identification of five interdependent discursive categories: (1) "clash of civilizations", purposive non-integration and dissimulated goals, (2) sovereignty, securitization and national identity protection, (3) migrants as biopolitical threats, (4) occupation memories and trauma and (5) (re)defining Hungary's ontological and geopolitical location. These five discursive strategies are interdependent since they all contribute to the creation of a cascade securitary argument contrary to Muslim migration movements framed by mnemonic foundations (Orbán, 2016a).

The paper concludes that, through these discursive categories, and mainly through the persistent articulation between occupation memories, subsequent historical traumas and migration (category four), Orbán was able to discursively link migration, asylum (conveniently represented as the same phenomena), (in)security, memory and trauma. The geopolitical consequences of such linkage deserve attention and were highlighted through discussions concerning the fifth discursive category.

In fact, Viktor Orbán's discourses, and the refusal to accept the European system for refugee allocation has put him at odds with EU institutions. However, countries like Poland and Slovakia, have shown sympathy towards Orban's perspectives regarding the dangers of migration flow. In this context, Orbán has been arguing that Hungary should (re)think its ontological location, dislocating it geopolitically from Western Europe towards Central, Eastern Europe and also towards the Russian sphere of influence. Such argument has complex geopolitical and normative consequences, directly articulated with the evolution of some Central and Eastern European countries' political regimes and also with developments in contemporary Russia, with whom Hungary has specific economic and political ties. 
A rupture, of a profound geopolitical and normative nature, seems to be emerging between Western EU countries and Central and Eastern EU countries. This fracture is particularly intricate, because some Central and Eastern EU countries, namely Hungary, the Czech Republic and Poland, have implemented illiberal policies (Barata, 2015). Also, Orbán's preferential ties with Russia are clearly meant to weaken the liberal and western normative and geopolitical dimensions of the EU, thus empowering the autocratic geopolitical dimension of Central and Eastern Europe, very well represented by Putin's messianic will to rebuild Russia's predominance in the countries of its "near abroad" and to lessen the geopolitical significance of the European Union project.

Therefore, it is crucial to deconstruct how European leaders, discuss migration by establishing an articulation among (in)security, memory and trauma and how, through the invocation of mnemonic elements, illiberal practices, namely in the migration and asylum arenas, as well as alliances with autocratic countries, are legitimized.

\section{References}

Aidin-Düzgit, S. (2013). Critical discourse analysis in analyzing European Union foreign policy: Prospects and challenges. Cooperation and Conflict, 49(3), 354-367. doi:10.1177/0010836713494999

Barata, C. (2015, April 30). Orbán está a construir uma 'democracia não liberal' na Hungria. Público. Retrieved from <https://www.publico.pt/2015/04/30/mundo/noticia/orban-esta-a-construir-uma-democracia-nao-liberal-na-hungria-1694164>.

Barata, C. (2016, October 2). Referendo da Hungria sobre refugiados não é válido. Público. Retrieved from <https://www.publico.pt/2016/10/02/mundo/noticia/referendo-da-hungria-sobre-refugiados-nao-e-valido-diz-sondagem-1745939>.

Casula, P., \& Jeronim P. (2009). The stabilization of Russia during the Putin presidency. Critical reflexions. InP. Casula \&J. Perovic (Eds.), Identities and politics during the Putin presidency. Stuttgart: Ibidem Press.

Charteris-Black, J. (2006). Britain as a container: immigration metaphors in 2005 election campaign. Discourse \& Society, 17(5), 563-581. Retrieved from http://das.sagepub. com/content/17/5/563.abstract.

Coddington, K., \& Micieli-Voutsinas. J. (2017, august). On trauma, geography and mobility: towards geographies of trauma. Emotion, Space and Society, 24, 52-56.

Darling, J. (2010). A city of sanctuary: The relational re-imagining of Sheffield's asylum politics. Transactions of the Institute of British Geographers, 35, 125-140.

Dittmer, J. (2010). Popular culture, geopolitics and identity. Lanham, MA: Rowmann \& Littlefield.

Drakulic, S. (2015 june 8). Competing for victimhood. Why Eastern Europe says no to refugees. Eurozine. Retrieved from <http://www.eurozine.com/articles/2015-11-04-drakulic-en.html>.

Edkins, J. (2003). Trauma and the memory of politics. Cambridge: Cambridge University Press. 
Erll, A. (2011). Memory in culture. Hampshire, England: Palgrave Macmillan.

European Commission, (2015). Commission Recommendation on a European Resettlement Scheme. (EU 2015/914). European Comission. Retrieved from <http://eur-lex.europa. eu/legal-content/EN/TXT/PDF/?uri=CELEX:32015H0914\&from=EN>.

Fairclough, N. (2003). Analysing discourse textual analysis for social research. London: Routledge.

Fairclough, N., \& Fairclough, I. (2012). Political discourse analysis: a method for advanced students. London: Routledge.

Fairclough, N., \& Wodak, R. (1997). Critical discourse analysis. In V. Dijk \& A. Teun (Eds.), Discourse as social interaction: a multidisciplinary introduction (pp. 258-284). London: Sage.

Ferreira, M., Ferreira, P., \& Mazzaglia. N. (2016). Liminality and migrant decision-making in the aftermath of the political and refugee crises in the Mediterranean, 2010-2013. In T. Bloom \& B. Gebrewold (Eds.), Understanding migrant decisions: from Sub-Saharan Africa to the Mediterranean region. UK: Routledge.

Flowerdew, J., Li, D., \& Tran, S. (2002). Discriminatory news discourse: some Hong Kong data. Discourse \& Society, 13(3), 1-27.

Fonseca, P., \& Ferreira, M. (2015). Through 'seas never before sailed': Portuguese government discursive legitimation strategies in a context of financial crisis. Discourse \& Society, 26(6), 682-711.

Goldman, M. (2011). Memory, diaspora, hysteria: Margaret Atwood's Alias Grace. In J. Creet \& A. Kitzman (Eds.), Memory and Migration (pp. 210-234). Toronto: University of Toronto Press.

Halbwachs, M. (1950). La mémoire collective. Chicoutimi: Université du Québec.

Huntington, S. (2011). The clash of civilizations and the remaking of world order. New York: Touchstone.

Hutchinson, E. (2010). Trauma and the politics of emotion. constituting identity, security and community after the Bali Bombing. International Relations, 1(24), 65-86.

Innes, A., Steele, B. (2014). Memory, trauma and ontological security. In E. Resende \& D. Budryte (Eds.), Memory and Trauma in International Relations (pp. 57-74). New York: Routledge.

Kaplan, E. A. (2005). Culture: the politics of terror and loss in media and literature. N.J.: Rutgers University Press.

Keegan, J. (2005). The Second World War. New York: Penguin Books.

Kim, D. (2004). The place of American Empire: Amerasian territories and late american modernity. Philosophy and Geography, 1(7), 195-121.

Kirk, A. (2016, january 21). Mapped: which country has the most immigrants?. Daily Telegraph. Retrieved from <http://www.telegraph.co.uk/news/worldnews/middleeast/12111108/ Mapped-Which-country-has-the-most-immigrants.html>.

Legg, S. (2007). Reviewing geographies of memory/forgetting. Environment and Planning, 2(39), 456-466.

Lewis, B. (1990, september). The roots of Muslim rage. The Atlantic, 3(266), 47-60. 
Light, D., \& Young C. (2010). Political identity, public memory and urban space: a case-study of Parcul Carol I, Bucharest from 1906 to the present. Europe-Asia Studies, 9(62), 1453 1478.

Mayer, T., \& Prantner C. (2015, december 10). Dunkle Schatten über Europas mitte. DerStandard.at. Retrieved from <http://derstandard.at/2000027770927/Dunkle-Schatten-ueber-Europas-Mittembridge $>$.

Müller, M. (2011). Doing discourse analysis in critical geopolitics. L'Espace Politique, 12(3). Retrieved from <http://journals.openedition.org/espacepolitique/1743>. doi:10.4000/ espacepolitique.1743

Nora, P. (1989). Between memory and history: les lieux de mémoire. Representations, 26, 7-24.

Olick, J., Vinitzky-Seroussy, V., \& Levy, D. (2011). Introduction. In J. Olick, V. Vinitzky-Seroussy \& D. Levy (Eds.), The collective memory reader (pp. 3-63). Oxford: Oxford University Press.

Orbán, V. (2015a). Prime Minister Viktor Orbán’s presentation at the 26th Bálványos Summer Open University and Student Camp. Website of the Hungarian Government. Retrieved from http://www.kormany.hu/en/the-prime-minister/the-prime-minister-s-speeches/ prime-minister-viktor-orban-s-presentation-at-the-26th-balvanyos-summer-openuniversity-and-student-camp (accessed 20 december, 2017).

Orbán, V. (2015b, september 17). Viktor Orbán’s speech at the 14th Kötcse civil picnic. Website of the Hungarian Government. Retrieved from <http://www.kormany.hu/en/ the-prime-minister/the-prime-minister-s-speeches/viktor-orban-s-speech-at-the14th-kotcse-civil-picnic> (accessed 20 december, 2017).

Orbán, V. (2015c, september 5). If we do not protect our borders, tens of millions of migrants will come. Website of the Hungarian Government. Retrieved from <http://www.kormany.hu/en/the-prime-minister/the-prime-minister-s-speeches/if-we-do-not-protect-our-borders-tens-of-millions-of-migrants-will-come> (accessed 20 december, 2017).

Orbán, V. (2015d, november 13). Prime Minister Viktor Orbán’s interview with Swiss weekly Weltwoche. Website of the Hungarian Government. Retrieved from <http://www.kormany.hu/en/the-prime-minister/the-prime-minister-s-speeches/prime-minister-viktor-orban-s-interview-with-swiss-weekly-weltwoche> (accessed 20 december, 2017).

Orbán, V. (2015e, november 9). Prime Minister Viktor Orbán’s speech at the Budapest Demographic forum. Website of the Hungarian Government.Retrieved from <http://www.kormany.hu/en/the-prime-minister/the-prime-minister-s-speeches/prime-minister-viktor-orban-s-speech-at-the-budapest-demographic-forum> (accessed 20 december, 2017).

Orbán, V. (2015f, september 13). Prime Minister Viktor Orbán’s interview with BILD Zeitung. Website of the Hungarian Government. Retrieved from <http://www.kormany.hu/en/ the-prime-minister/the-prime-minister-s-speeches/prime-minister-viktor-orban-sinterview-with-bild-zeitung $>$ (accessed 20 december, 2017).

Orbán, V. (2015g, september 4). If we do not protect our borders tens of millions of migrants will come. Magyarország jobban teljesít. Retrieved from <http://2010-2015.miniszterel- 
nok.hu/in_english_article/if_we_do_not_protect_our_borders_tens_of_millions_of_ migrants_will_come_interview> (accessed 20 december, 2017).

Orbán, V. (2015h, september 3). Those who are overwhelmed cannot offer shelter to anyone. Website of the Hungarian Government. Retrieved from <http://www.kormany.hu/en/ the-prime-minister/the-prime-minister-s-speeches/those-who-are-overwhelmedcannot-offer-shelter-to-anyone> (accessed 20 december, 2017).

Orbán, V. (2015i, november 23). Viktor Orbán: Putin has no personality. Politico. Interview by Matthew Kaminski. Retrieved from <http://www.politico.eu/article/viktor-orban-putin-has-no-personality/> (accessed 20 december, 2017).

Orbán, V. (2016a, february 25). Hungary’s prime minister says accepting Syrian refugees also means importing terrorism, criminalism anti-Semitism and homophobia. Business Insider. Interview gave to Kai Diekmann. Retrieved from < http://www.businessinsider. com/viktor-orban-interview-refugee-migrant-hungary-2016-2>.

Orbán, V. (2016b, february 28). Prime Minister Viktor Orbán’s State of the Nation Address. Website of the Hungarian Government. Retrieved from <http://www.kormany.hu/en/ the-prime-minister/the-prime-minister-s-speeches/prime-minister-viktor-orban-sstate-of-the-nation-address $>$ (accessed 20 december, 2017).

Orbán, V. (2016c, march, 15). Speech by Prime Minister Viktor Orbán. Website of the Hungarian Government. Retrieved from <http://www.kormany.hu/en/the-prime-minister/the-prime-minister-s-speeches/speech-by-prime-minister-viktor-orban-on-15march> (accessed 20 december, 2017).

Orbán, V. (2016d, april 20). Viktor Orbán and Helmut Kohl: Europe cannot be a new home to millions of people in need around the world. Website of the Hungarian Government. Retrieved from <http://www.kormany.hu/en/the-prime-minister/news/viktor-orbanand-helmut-kohl-europe-cannot-be-a-new-home-to-millions-of-people-in-needaround-the-world $>$ (accessed 10 september, 2017).

Orbán, V. (2016f, december 7). Prime Minister Viktor Orbán’s speech at the 6th meeting of the Hungarian Diaspora Council. Website of the Hungarian Government. Retrieved from $<$ http://www.kormany.hu/en/the-prime-minister/the-prime-minister-s-speeches/ prime-minister-viktor-orban-s-speech-at-the-6th-meeting-of-the-hungarian-diaspora-council> (accessed 10 september, 2017).

Orbán, V. (2016g, december 1). Prime Minister Viktor Orbán’s laudation when presenting the Grand Cross of the Hungarian Order of Merit to Prime Minister of Bulgaria Boyko Borissov. Website of the Hungarian Government. Retrieved from < http://www.kormany. $\mathrm{hu} / \mathrm{en} /$ the-prime-minister/the-prime-minister-s-speeches/prime-minister-viktor-orban-s-laudation-when-presenting-the-grand-cross-of-the-hungarian-order-of-meritto-prime-minister-of-bulgaria-boyko-borissov> (accessed 10 september, 2017).

Orbán, V. (2016h, october 23). Prime Minister Viktor Orbán’s speech at the official ceremony marking the 60th anniversary of the 1956 Revolution. Website of the Hungarian Government. Retrieved from <http://www.kormany.hu/en/the-prime-minister/the-primeminister-s-speeches/prime-minister-viktor-orban-s-speech-at-the-official-ceremony-marking-the-60th-anniversary-of-the-1956-revolution> (accessed 10 september, 2017). 
Orbán, V. (2016i, december 22). Prime Minister Viktor Orbán’s press conference after the meeting of the European Council. Website of the Hungarian Government. Retrieved from $<$ http://www.kormany.hu/en/the-prime-minister/the-prime-minister-s-speeches/ prime-minister-viktor-orban-s-press-conference-after-the-meeting-of-the-europeancouncil> (accessed 10 september, 2017).

Orbán, V. (2016k, september 30). Provided there are Christians there will be a spiritual upturn. Website of the Hungarian Government. Retrieved from <http://www.kormany.hu/ en/the-prime-minister/the-prime-minister-s-speeches/provided-there-are-christiansthere-will-be-a-spiritual-upturn> (accessed 10 september, 2017).

Orbán, V. (20161, september 22). I love this country, and I do not want to see anyone change it under orders from outside. Website of the Hungarian Government. Retrieved from $<$ http://www.kormany.hu/en/the-prime-minister/the-prime-minister-s-speeches/viktor-orban-i-love-this-country-and-i-do-not-want-to-see-anyone-change-it-under-orders-from-outside> (accessed 10 september, 2017).

Orbán, V. (2016n, september 11). Prime Minister Viktor Orbán's press statement after the meeting of the Prime Ministers of the Visegrád Four and Ukraine. Website of the Hungarian Government. Retrieved from <http://www.kormany.hu/en/the-prime-minister/ the-prime-minister-s-speeches/prime-minister-viktor-orban-s-press-statement-afterthe-meeting-of-the-prime-ministers-of-the-visegrad-four-and-ukraine> (accessed 10 september, 2017).

Orbán, V. (2016o, july 1). Are you opposed to peace?. Website of the Hungarian Government. Retrieved from <http://www.kormany.hu/en/the-prime-minister/the-prime-ministers-speeches/are-you-opposed-to-peace > (accessed 10 september, 2017).

Orbán, V. (2016r). Prime Minister Viktor Orbán’s press statement following his talks with President of Russia Vladimir Vladimirovich Putin. Website of the Hungarian Government. Retrieved from <http://www.kormany.hu/en/the-prime-minister/the-prime-ministers-speeches/prime-minister-viktor-orban-s-press-statement-following-his-talks-withpresident-of-russia-vladimir-vladimirovich-putin> (accessed 10 september, 2017).

Orbán, V. (2016s). Prime Minister Viktor Orbán’s statement at the joint press conference with Prime Minister of the Republic of Poland Beata Szydło, following their meeting in Budapest. Website of the Hungarian Government. Retrieved from < http://www.kormany. $\mathrm{hu} / \mathrm{en} /$ the-prime-minister/the-prime-minister-s-speeches/prime-minister-viktor-orban-s-statement-at-the-joint-press-conference-with-prime-minister-of-the-republicof-poland-beata-szyd-o-following-their-meeting-in-budapest> (accessed 10 september, 2017).

Orbán, V. (2016t, january 19). Prime Minister Viktor Orbán’s speech delivered on the day of remembrance for ethnic Germans rounded up and deported from Hungary. Website of the Hungarian Government. Retrieved from <http://www.kormany.hu/en/ the-prime-minister/the-prime-minister-s-speeches/prime-minister-viktor-orban-sspeech-delivered-on-the-day-of-remembrance-for-ethnic-germans-rounded-up-anddeported-from-hungary> (accessed 10 september, 2017).

Orbán, V. (2017a, june 12). Prime Minister Viktor Orbán’s reply to opposition comments on his address in Parliament before the start of daily business. Website of the Hungarian Government. Retrieved from <http://www.kormany.hu/en/the-prime-minister/the- 
prime-minister-s-speeches/prime-minister-viktor-orban-s-reply-to-opposition-comments-on-his-address-in-parliament-before-the-start-of-daily-business $>$ (accessed 10 september, 2017).

Orbán, V. (2017b, june 12). Prime Minister Viktor Orbán’s address in Parliament before the start of daily business. Website of the Hungarian Government. Retrieved from $<\mathrm{http}$ //www. kormany.hu/en/the-prime-minister/the-prime-minister-s-speeches/prime-ministerviktor-orban-s-address-in-parliament-before-the-start-of-daily-business-20170614> (accessed 10 september, 2017).

Orbán, V. (2017c, may 25). Prime Minister Viktor Orbán’s opening speech at the 2nd Budapest World Congress of Families. Website of the Hungarian Government. Retrieved from $<$ http://www.kormany.hu/en/the-prime-minister/the-prime-minister-s-speeches/ prime-minister-viktor-orban-s-opening-speech-at-the-2nd-budapest-world-congress-of-families $>$ (accessed 10 september, 2017).

Orbán, V. (2017d, may 20). Prime Minister Viktor Orbán's speech at the 11th Congress of the Slovenian Democratic Party (SDS). Website of the Hungarian Government. Retrieved from <http://www.kormany.hu/en/the-prime-minister/the-prime-minister-sspeeches/prime-minister-viktor-orban-s-speech-at-the-11th-congress-of-the-slovenian-democratic-party-sds $>$ (accessed 10 september, 2017).

Orbán, V. (2017e, may 17). Interview with Viktor Orbán on Magyar Televizió (Hungarian public television) summarizing his recent visit to Beijing. Website of the Hungarian Government. Retrieved from <http://www.kormany.hu/en/the-prime-minister/theprime-minister-s-speeches/interview-with-viktor-orban-on-magyar-televizio-hungarian-public-television-summarising-his-recent-visit-to-beijing $>$ (accessed $10 \mathrm{sep}$ tember, 2017).

Orbán, V. (2017f, june 30). Press statement by Prime Minister Viktor Orbán, after his talks with Binali Ylldırım, Prime Minister of the Republic of Turkey. Website of the Hungarian Government. Retrieved from <http://www.kormany.hu/en/the-prime-minister/theprime-minister-s-speeches/press-statement-by-prime-minister-viktor-orban-afterhis-talks-with-binali-y-ld-r-m-prime-minister-of-the-republic-of-turkey> (accessed 10 september, 2017).

Orbán, V. (2017g, april 16). Interview with Prime Minister Viktor Orbán on the Kossuth Radio programme 'Sunday News'. Website of the Hungarian Government. Retrieved from $<$ http://www.kormany.hu/en/the-prime-minister/the-prime-minister-s-speeches/ interview-with-prime-minister-viktor-orban-on-the-kossuth-radio-programme-sunday-news $>$ (accessed 10 september, 2017).

Orbán, V. (2017i). Easter interview with Prime Minister Viktor Orbán in Hungarian daily Magyar Idök. Website of the Hungarian Government. Retrieved from <http://www. kormany.hu/en/the-prime-minister/the-prime-minister-s-speeches/easter-interview-with-prime-minister-viktor-orban-in-hungarian-daily-magyar-idok> (accessed 10 september, 2017).

Orbán, V. (2017j february 10). Prime Minister Viktor Orbán's State of the Nation Address. Website of the Hungarian Government. Retrieved from <http://www.kormany.hu/en/ the-prime-minister/the-prime-minister-s-speeches/prime-minister-viktor-orban-sstate-of-the-nation-address-20170214> (accessed 10 september, 2017). 
Orbán, V. (2017k, march 30). Speech of Viktor Orbán at the EPP Congress. Website of the Hungarian Government. Retrieved from <http://www.kormany.hu/en/ the-prime-minister/the-prime-minister-s-speeches/speech-of-viktor-orban-atthe-epp-congress $>$ (accessed 10 september, 2017).

Orbán, V. (2017l, march 17). Prime Minister Viktor Orbán on Kossuth Radio’s 180 Minutes programme. Website of the Hungarian Government. Retrieved from <http:// www.kormany.hu/en/the-prime-minister/the-prime-minister-s-speeches/primeminister-viktor-orban-on-kossuth-radio-s-180-minutes-programme20170319> (accessed 10 september, 2017).

Órban, V. (2017m, march 15). Viktor Orbán's speech on the anniversary of the 1848 Revolution. Website of the Hungarian Government. Retrieved from <http://www.kormany. hu/en/the-prime-minister/the-prime-minister-s-speeches/viktor-orban-s-speechon-the-anniversary-of-the-1848-revolution> (accessed 10 september, 2017).

Orbán, V. (2017n, march 7). Viktor Orbán's speech at the ceremonial swearing-in of new border hunters. Website of the Hungarian Government. Retrieved from <http:// www.kormany.hu/en/the-prime-minister/the-prime-minister-s-speeches/viktor-orban-s-speech-at-the-ceremonial-swearing-in-of-new-border-hunters $>$ (accessed 10 september, 2017).

Orbán, V. (2017o, january 23). Prime Minister Viktor Orbán’s speech at the Lámfalussy Conference. Miniszterelnök.hu. Retrieved from <http://www.miniszterelnok.hu/ prime-minister-viktor-orbans-speech-at-the-lamfalussy-conference/> (accessed 10 september, 2017).

Ó Tuathail, G., \& Agnew, J. (1992). Geopolitics and discourse: practical geopolitical reasoning in American foreign policy. Political Geography, 11(2), 190-204.

Ó Tuathail, G. (1999). Critical geopolitics: the politics of writing global space. London: Routledge.

Ó Tuathail, G. (2005). Understanding critical geopolitics: geopolitics and risk society. Journal of Strategic Studies, 3(22), 107-124.

Paterson, T. (2012, january 7). Curtain comes down on liberal hungary. Independent. Retrieved from <http://www.independent.co.uk/news/world/europe/curtain-comesdown-on-liberal-hungary-6286332.html>.

Reisigl, M., \& Ruth Wodak, R. (2001). Discourse and discrimination: rhetorics of racism and anti-semitism. London: Routledge.

Saïd, E. (1996). The myth of the clash of civilizations. Lecture at the University of Massachusets, Amherst. Youtube. Retrieved from <https://www.youtube.com/ watch?v=aPSpONiEG8> (accessed 24 january, 2017).

Saxonberg, S. (2001). The fall: A comparative study of the end of Communism in Czechoslovakia, East Germany, Hungary and Poland. London: Routledge.

Smith, A. D. (2010). Nationalism: theory, ideology, history. Cambridge: Polity Press.

Szalai A., \& Gőbl, G. (2015). Securitizing migration in contemporary Hungary. (Working Paper). Central European University. Retrieved from <https://cens.ceu.edu/sites/ cens.ceu.edu/files/attachment/event/573/szalai-goblmigrationpaper.final.pdf> (accessed 24 january, 2017). 
Tahoor, I. (2015, september 4). Hungary's Orban invokes Ottoman invasion to justify keeping refugees out. The Washington Post. Retrieved from <https:/www.washingtonpost.com/news/worldviews/wp/2015/09/04/hungarys-orban-invokes-ottoman-invasion-to-justify-keeping-refugees-out/?utm_term $=.757 \mathrm{c} 3 \mathrm{~b} 3 \mathrm{ca} 855>$.

The Economist. (2016, october 3). Orbán fails to win his referendum against migrants. The Economist. Retrieved from <https://www.economist.com/news/europe/21708083anti-refugee-publicity-ploy-falls-far-short-needed-turnout-viktor-orban-failswin-his $>$.

Till, K., \& Kuusisto-Arponen, A. (2015). Towards responsible geographies of memory. complexities of place and the ethics of remembering. Erdkunde, 69(4), 291-306.

Valentine, G., Piekut, A., Winiarska, A., Harris, C., \& Jackson, L. (2015). Mapping the meaning of 'difference' in Europe: A social topography of prejudice. Ethnicities, 15(4), $568-585$.

Van Dijk, T. (2009). Critical discourse studies: A sociocognitive approach. In R. Wodak \& M. Meyer (Eds.), Methods of critical discourse analysis (pp. 62-85). London: Sage.

Van Dijk, T. (1997). What is political discourse analysis?. In J. Blommaert \& C. Bulcaen (Eds.), Political linguistics (pp. 11-52). Amsterdam: John Benjamins Publishing Company.

Van Dijk, T. (1998). Ideology: A multidisciplinary approach. London: Sage Publications.

Wodak, R. (2001). What CDA is about - A summary of its history, important concepts and its developments. In R. Wodak \& M. Meyer (Eds.), Methods of critical discourse analysis (pp. 1-14). London: Sage.

Zhurzhenko, T. (2007, october 5). The geopolitics of memory. Eurozine. Retrieved from $<\mathrm{http}: / /$ www.eurozine.com/the-geopolitics-of-memory/>. 


\section{Sobre a autora}

MARIA JoÃo Militão ferreira (PhD) é Professora Auxiliar do Instituto Superior de Ciências Sociais e Políticas da Universidade de Lisboa. As suas áreas de investigação compreendem as políticas territoriais da União Europeia, nomeadamente, as políticas migratórias e securitárias, as práticas discursivas que legitimam as políticas públicas, designadamente em momentos de "excepcionalidade política", e ainda as práticas discursivas em política externa. Um outro tema em que tem produzido trabalho académico respeita à área do trauma, da memória e das práticas mnemónicas e como estas influenciam as políticas externas das comunidades políticas. O enquadramento teórico que permeia as suas publicações é o enquadramento pós- estruturalista e as suas manifestações ao nível da teoria das Relações Internacionais. Neste sentido, tem vindo a privilegiar o estudo crítico das práticas discursivas ao nível da Análise de Política Externa, dos Estudos de Segurança, da Geopolítica e dos Estudos Estratégicos. É autora de vários artigos publicados em revistas internacionais indexadas da especialidade, de diversos capítulos em obras publicadas por editoras de referência (Routledge), bem como de manuais universitários.

\footnotetext{
About the author

MARIA JOÃo MILITÃo FERREIRA (PhD) is an Assistant Professor of the Institute of Social and Political Sciences at the University of Lisbon. Her investigation areas consist of European Union territorial policies such as migratory and security policies, discursive practices that legitimize public policies, particularly at times of "political exceptionality", and also discursive practices in foreign policy. Another subject of her academic work concerns trauma, memory and mnemonic practices, and how these influence the foreign policies of political communities. The theoretical framework that permeates her publications is the post-structuralist framework and its manifestations at the level of International Relations theory. This has led her to privilege the study of discursive practices in Foreign Policy Analysis, Security Studies, Geopolitics and Strategic Studies. She is the author of several journal articles in specialty international journals, has contributed various chapters to reference editions (e.g. Routledge), and has had her work included in university manuals.
} 